\title{
Contribution of the post-collisional A-type granite to the formation of the Tebai gold deposit in Alxa League, Inner Mongolia, China
}

\author{
Xuan Yang ${ }^{1, a}$, An Jian Wang ${ }^{1, b}$ and Yi Ke Li ${ }^{1, c}$ \\ ${ }^{1}$ Institute of Mineral Resources, Chinese Academy of Geological Sciences, Beijing, 100037, China. \\ aYangxvan@163.com, bajwang@cags.ac.cn, ${ }^{\mathrm{c}} 275589375 @ q q . c o m$
}

Keywords: ore-forming fluid, gold deposit, A-type granite, geochemistry, the North China Craton.

\begin{abstract}
The Tebai gold deposit is located in the Yabulai - Bayinuoer archaeozoic continental arc fold belt in the east of Alashan platform uprise. The ore bodies occur in the Carboniferous slate and phyllite of the Mesoproterozoic Agulucou Formation, surrounding by the Hercynian Guancaitaolugai granite porphyry. This gold deposit belongs to the black rock series gold deposit. The ore-forming fluid has the characteristics of low temperature $\left(150^{\circ} \mathrm{C}-250^{\circ} \mathrm{C}\right)$, low salinity $(1 \%$ $6 \%)$, low density $\left(0.7 \mathrm{~g} / \mathrm{cm}^{3}-0.9 \mathrm{~g} / \mathrm{cm}^{3}\right)$. The hydrogen and oxygen isotopes and trace elements features of the ore-forming fluid accoed with the characteristics of the magmatic hydrothermal mixing meteoric water. Concerning the geology characteristics, it is confirmed that this fluid sourced from the Guancaitaolugai granite porphyry. This granite porphyry is a post-collisional A-type granite, which may be formed by the post-collisional extension of the Zongnaishan-Shalazha volcanic arc and the Alxa Block. The metallogenic process and fluid feature of the Tebai gold deposit are similar with the other black rock series gold deposits along western part of the northern margin at the North China Craton, which reflect the unique characteristics of the black rock series gold deposits in this area.
\end{abstract}

\section{Introduction}

Nowadays the black rock series gold deposit has been an important gold deposit. Gold deposits of this kind have some distinctive features, such as the wall rocks are always rich of organic carbon, the ore bodies are always layered, and metallogenic process normally includes two or more stages[1,2,3]. The most important area that pregnants black rock series gold deposits around the world is the Central Asia, which has an accumulated gold reserves of more than 8000t[4]. In recent years, some black rock series gold deposits have been explored in Xinjiang region and Inner Mongolia region, China, which has been a hot topic in modern mineral deposits. Among those newly explored deposits mention above, the Tebai gold deposit is a special one, because it is located in the Alxa League, Where great confusions about geology have been existed for a long time but mineral resources are in great need. In this case the author carried out related research works on the Tebai gold deposit.

\section{Metallogenic Geological Background}

The Tebai gold deposit is located in the Yabulai - Bayinuoer archaeozoic continental arc fold belt in the east of Alashan platform uprise. The orebodies occur in the Carboniferous slate and phyllite of the Mesoproterozoic Agulucou Formation. The deposit is located in the axis of a small anticline that has steep (about $7^{\circ}$ ) wings. The magma activities were quite strong. The Hercynian Tebai quartz diorite and Guancaitaolugai granite porphyry have instructed into the mining area as a result. 


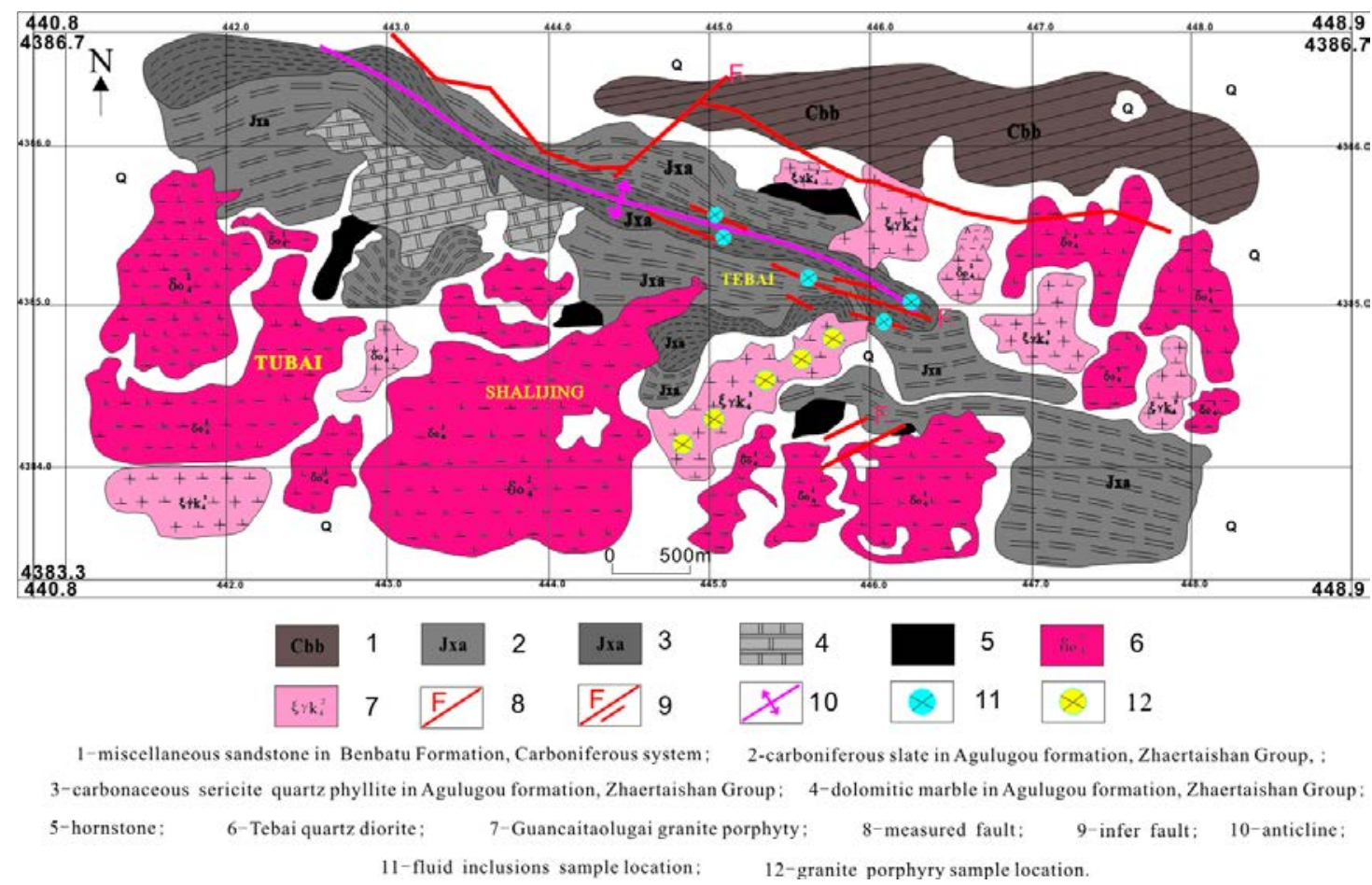

Fig. 1 Geological map of the Tebai mining area

There are two ore bodies in the mining area, and the northern ore body is the main one. The main ore body is layered with the $300^{\circ}$ strike that is in accordance with the strike of anticline axis. The dip of ore body is NE with the dip angle $45^{\circ}$ to $78^{\circ}$. The ore body is $83 \mathrm{~m}$ to $680 \mathrm{~m}$ in length, $2.1 \mathrm{~m}$ to $3.5 \mathrm{~m}$ in thickness, and its grade is 3.1 to $4.4 \mathrm{ppm}$. There are 2 kinds of the ores: lenticular quartz vein type ore and reticulate quartz vein type ore. The ores are in crystal grain texture, lenticular structure or reticular vein structure. The main minerals in the ores are pyrites and limonites. The alteration of wall rocks is weak relatively, which are mainly silicification, pyrite mineralization and sericitization.

The mineralization process of this gold deposit can be divides into 3stages based on generation order of the minerals seen in the field: (1) quartz vein-metal sulphides stage; (2) lenticular quartz vein-gold bearing pyrite stage; (3) reticulate quartz vein-gold bearing pyrite stage.

\section{Ore-forming Fluid Features}

\section{Temperature, Salinity, Density, and Pressure.}

Through the microscopic temperature measurement to fluid inclusions in the gold-bearing quartz veins, the characteristics can be described as follows. In the 1st mineralization stage, the temperature of the fluid inclusions concentrated into $300^{\circ} \mathrm{C}$ to $350^{\circ} \mathrm{C}$, and the salinity into $16 \%$ to $20 \%$, while the average density is $0.8 \mathrm{~g} / \mathrm{cm}^{3}$, and pressure varies from 60MPa to 90MPa. In the 2nd mineralization stage, the temperature of the fluid inclusions concentrated into $200^{\circ} \mathrm{C}$ to $250^{\circ} \mathrm{C}$, and the salinity into $4 \%$ to $8 \%$, while the density is $0.7 \mathrm{~g} / \mathrm{cm}^{3}$ to $0.8 \mathrm{~g} / \mathrm{cm}^{3}$, and pressure is about $45 \mathrm{MP}$. In the 3rd mineralization stage, the temperature of the fluid inclusions concentrated into $150^{\circ} \mathrm{C}$ to $200^{\circ} \mathrm{C}$, and the salinity into $1 \%$ to $4 \%$, while the density is around $0.9 \mathrm{~g} / \mathrm{cm}^{3}$, and pressure is about 20MPa.

\section{Hydrogen and Oxygen Isotopes.}

The hydrogen and oxygen isotopic composition of the 4 samples are similar. $\delta \mathrm{D}_{\mathrm{V} \text {-SMOw }}$ in the 2nd mineralization stage varies from -84.6\%o to-84.5\%, while $\delta^{18} \mathrm{O}_{\mathrm{H} 2 \mathrm{O}}$ varies from $1.8 \%$ o to $2.3 \%$. $\delta \mathrm{D}_{\mathrm{V} \text {-SMOw }}$ in the 3rd mineralization stage varies from $-91.6 \%$ o to $-91.1 \%$, while $\delta^{18} \mathrm{O}_{\mathrm{H} 2 \mathrm{O}}$ varies from $2.1 \%$ o to $3.5 \%$. 


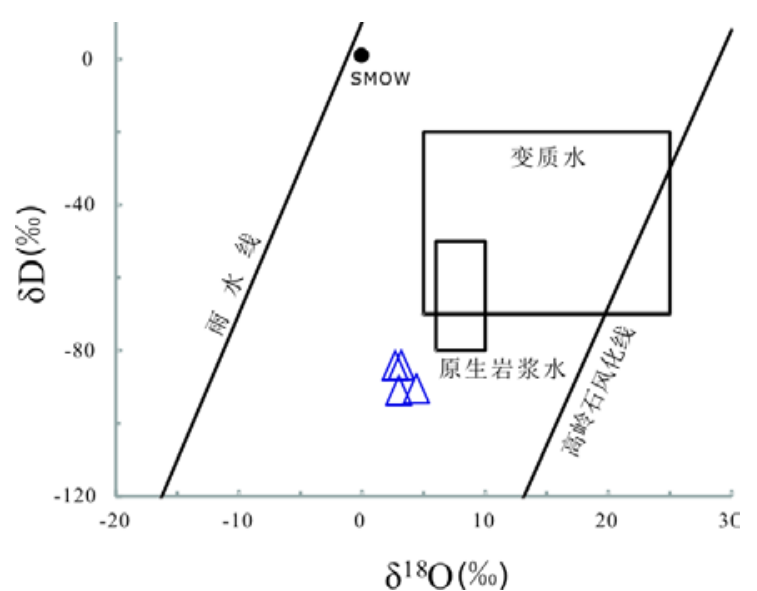

Fig. $2 \delta^{18} \mathrm{O}_{\mathrm{H} 2 \mathrm{O}-} \delta \mathrm{D}$ diagram of the ore-forming fluids in the Tebai gold deposit(afer H.P. Taylor,1974[5])

\section{Trace elements and REEs.}

The samples texted are among 1st to 3rd mineralization stage. The curve shapes of these samples are close. The fluid is relatively rich of $\mathrm{Ba}, \mathrm{Pb}, \mathrm{Sr}$ and lack of $\mathrm{Rb}, \mathrm{Th}, \mathrm{Nb}, \mathrm{Zr}, \mathrm{Y}, \mathrm{Yb}$. All the REE distribution model of these samples are right-leaning type, and 3 of them show the W-type four components effect. The $\Sigma$ REE content ranges from $0.106 \times 10-9$ to $66.933 \times 10-9$.

\section{Geochemical Features of the Guancaitaolugai Granite Porphyry}

\section{Whole Rock Geochemistry.}

Among the 5 samples, the $\mathrm{SiO}_{2}$ content varies from $72.84 \%$ to $79.37 \%$ with the average $74.59 \%$, which shows the rock is a kind of acidic magma rocks. The all alkali content $\left(\mathrm{Na}_{2} \mathrm{O}+\mathrm{K}_{2} \mathrm{O}\right)$ of these samples changes from $7.10 \%$ to $9.35 \%$ with the average $8.75 \%$. The $\mathrm{Al}_{2} \mathrm{O}_{3}$ content varies from $10.63 \%$ to $14.04 \%$ with the average $13.28 \%$ and the Aluminum saturation index(A/CNK) is 1.10 to 1.16. The $\mathrm{CaO}$ content changes from $0.19 \%$ to $0.45 \%$ with the average $0.29 \%$. It is known from the samples that the rock is rich of LILE like Rb, Th, U, K and LREE relatively, and the rock is lack of HFSE like Ta, Nb, P, Ti and Ba, Sr, Eu. The REE distribution model of these samples are similarly right-leaning type. The $\Sigma$ REE content ranges from $158.61 \times 10^{-6}$ to $249.07 \times 10^{-6}$ with the average $210.05 \times 10^{-6}$.

\section{Sr-Nd Isotopic Geochemistry.}

The granite porphyry have relatively high $\mathrm{Rb} / \mathrm{Sr}(1.4580$ to 1.5660$)$ and higher $\mathrm{I}_{\mathrm{Sr}}(0.707221$ to $0.707365) .{ }^{87} \mathrm{Sr} /{ }^{86} \mathrm{Sr}$ is 0.723768 to $0.724725 .{ }^{143} \mathrm{Nd} /{ }^{144} \mathrm{Nd}$ is 0.512289 to $0.512329 . \varepsilon \mathrm{Nd}_{(\mathrm{t})}$ is -3.7 to -3.0 .

\section{Discussion}

\section{Source of the Fluid.}

The main mineralization stage ore-forming fluid has the characteristics of low temperature $\left(150^{\circ} \mathrm{C}\right.$ $\left.-250^{\circ} \mathrm{C}\right)$, low salinity $(1 \%-6 \%)$, low density $\left(0.7 \mathrm{~g} / \mathrm{cm}^{3}-0.9 \mathrm{~g} / \mathrm{cm}^{3}\right)$, which are close to magmatic hydrothermal. On the hydrogen and oxygen isotopes features, $\delta \mathrm{D}_{\mathrm{V} \text {-SMOw }}$ ranges from $-91.6 \%$ o to -84.5\%, and $\delta^{18} \mathrm{O}_{\mathrm{H} 2 \mathrm{O}}$ ranges from $1.8 \%$ to $3.5 \%$, which show the features of magmatic hydrothermal mixing meteoric water. On the trace elements features, the fluid has low $\mathrm{Rb} / \mathrm{Sr}$, high $\mathrm{Zr} / \mathrm{Hf}$, relatively low $\mathrm{Nb}$ content and very low Ta content, which are also close to the magmatic hydrothermal. The source of the ore-forming fluid is unique because different samples show the similar curves of trace elements spidergram ( primitive mantle-normalized) and REE distribution patterns ( chondrite-normalized). Concerning the contact relationship of the intrusions in deposit area, it is inferred that the fluid sourced from the Guancaitaolugai granite porphyry.

Diagenetic Background of the Guancaitaolugai Granite Porphyry.

All of the Guancaitaolugai granite porphyry samples fall into the overlapping regions of post-collisional granite and continental collisional granite in the A/CNK-A/NK diagram. But all of 
the samples mention above fall into the post-collisional granite region in the $\mathrm{SiO}_{2}-{ }^{\mathrm{T}} \mathrm{FeO} /\left({ }^{\mathrm{T}} \mathrm{FeO}+\mathrm{MgO}\right)$ diagram. That is to say this granite porphyry is an A-type granitoid origined by the post-collisional magma activity[6]. It is distinguished that this granite belongs to A2-type granitoid, also named as post-collisional granitoid[7], in the Nb-Y-3Ga diagram. In the ${ }^{87} \mathrm{Sr} /{ }^{86} \mathrm{Sr}-{ }^{143} \mathrm{Nd} /{ }^{144} \mathrm{Nd}$ diagram, samples of this granite occurred close to the EM II area, which indicates a lot of crust material have been mixed in as the process of granite conformation[8]. Concerning the tectonic background[9], this granite porphyry may be formed by the post-collisional extension of the Zongnaishan-Shalazha volcanic arc and the Alxa Block. In fact, other black rock series located along the western part of the northern margin at the Northern China Craton are always related to granites of this kind in the same diagenetic background[10,11].
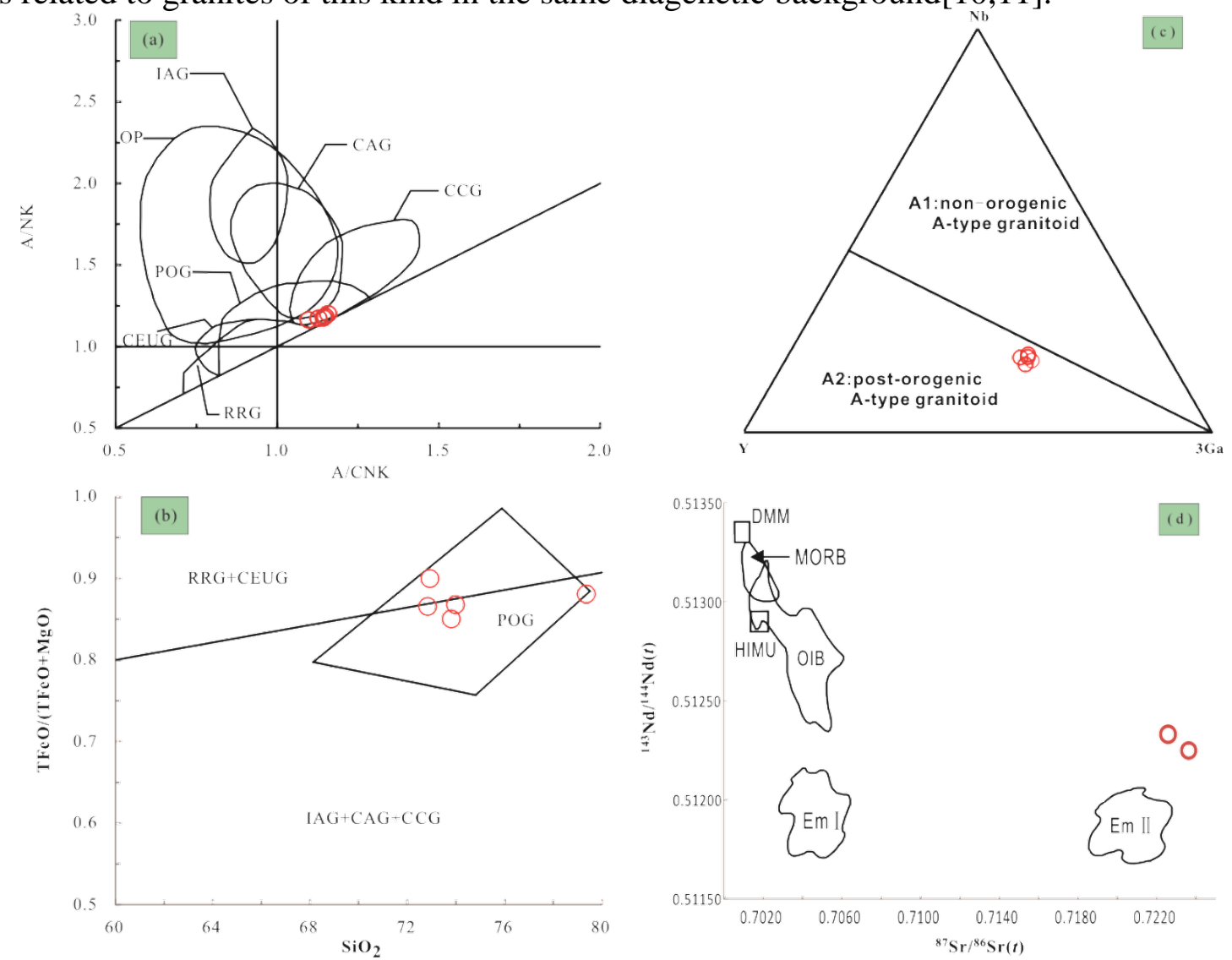

a-A/CNK-A/NK diagram (after H. Ran et al., 2012[6]);

b $-\mathrm{SiO} 2-\mathrm{TFeO} /(\mathrm{TFeO}+\mathrm{MgO})$ diagram (after $\mathrm{H}$. Ran et al., 2012[6]);

c-A type granitoid Nb-Y-3Ga diagram(after X.H. Zhang et al., 2010[11]).

d- $\mathrm{Sr}-\mathrm{Nd}$ isotope diagram(after A. Zindler et al., 1986[8]).

Fig. 3 Diagenetic setting discrimination of the Guancaitaolugai granite porphyries

\section{Conclusions}

The metallogenic process of the Tebai gold deposit is closely related with its surrounding granite porphyry, just the same with the other black rock series gold deposits along western part of the northern margin at the North China Craton. This granite porphyry was formed by the post-collisional extension of the Zongnaishan-Shalazha volcanic arc and the Alxa Block. Furthermore, the ore-forming fluid of this gold deposit has the feature of magmatic hydrothermal mixing meteoric water, which reflect the unique characteristics of the black rock series gold deposits in this area. 


\section{Acknowledgments}

This work was financially supported by China Geological Investigation Fund 1212011220870 , 12120114077201 and 12120114027701 . As the corresponding author, Professor An Jian Wang has carried out a far-sighted guidance on this paper. I also appreciate teacher Yi Ke Li for his concrete suggestions for this paper.

\section{References}

[1] R.R. Large, S.W. Bull, V.V. Maslennikov, A carbonaceous sedimentary source-rock model for Carlin-Type and Orogenic Gold Deposit, J. Economic Geology. 166(2011): 331-358.

[2] P. Pasava, H. Frimmel, A. Vymazalova, P. Dobes, A.J. Jukov, R.I. Koneev, A two-stage evolution model for the Amantaytau orogenic-type gold deposit in Uzbekistan, J. Miner Deposita. 48(2013): 825-840.

[3] S. Meffre, R.R. Large, J.A. Steadman, D.D. Gregory, A.S. Stepanov, V.S. Kamenetsky, K. Ehrig, R.J. Scott, Multi-stage enrichment processes for large gold-bearing ore deposits, J. Ore Geology Reviews. 76(2016): 268-279.

[4] T.M. Porter, An overview of the world's porphyry of other hydrothermal $\mathrm{Cu}$ and Au deposits and their distribution, J. Conference Proceedings. (1998): 3-17.

[5] H.P. Taylor, The application of oxygen and hydrogen isotope studies to problems of hydrothermal alteration and ore depositon, J. Economic Geology. 69(1974): 843-883.

[6] H. Ran, W.J. Zhang, Z.B. Liu, Geochemical characteristics and LA-ICP-MS zircon U-Pb dating of thr Late Permian monzogranite in Hanggale, Alax Right Banner, Inner Mongolia, J. Geological Bulletin of China. 31(2012): 1565-1575.

[7] G.N. Eby. Chemical subdivision of the A-type granitoids: Petrogenetic and tectonic implications, J. Geology. 20(1992): 641-644.

[8] A. Zindler, S. Hart, Chemical geodynamics, J. Annual Review of Earth and Planetary Science Letters. 14(1986): 493-571.

[9] T.R. Wu, G.Q. He, Tectonic units and their fundanmental characteristics on the northern margin for the Alxa Block, J. Acta Geol Sin. 6(1993): 373-385.

[10] S.H. Zhang, Y. Zhao, J.M. Liu, J.M. Hu, B. Song, J. Liu, H. Wu, Geochronology, geochemistry and tectonic setting of the Late Paleozoic-Early Mesozoic magmatism in the northern margin of the North China Block: A preliminary review, J. Acta Petrologia et Mineralogica. 29(2010): 824-842.

[11] X.H. Zhang, M.G. Zhai, Magmatism and its metallogenetic effects during the Paleozoic continental crustal construction in northern North China: An overview, J. Acta Petrologica Sinica, 26(2010): 1329-1341. 